University of Wollongong

Research Online

Faculty of Law - Papers (Archive)

Faculty of Business and Law

$1-1-2009$

\title{
Shhh ... we can't tell you: an update on the naming prohibition of young offenders
}

Robyn Lincoln

Bond University

Duncan Chappell

University of Wollongong, duncanc@uow.edu.au

Follow this and additional works at: https://ro.uow.edu.au/lawpapers

Part of the Law Commons

\section{Recommended Citation}

Lincoln, Robyn and Chappell, Duncan: Shhh ... we can't tell you: an update on the naming prohibition of young offenders 2009, 476-484.

https://ro.uow.edu.au/lawpapers/74

Research Online is the open access institutional repository for the University of Wollongong. For further information contact the UOW Library: research-pubs@uow.edu.au 


\title{
Shhh ... we can't tell you: an update on the naming prohibition of young offenders
}

\begin{abstract}
Prohibitions on the naming of young offenders in criminal proceedings remain a controversial issue both in Australia and abroad. Despite international obligations, like those contained in the UN Convention on the Rights of the Child, to protect the privacy of young people in conflict with the law jurisdictions like the Northern Territory (NT) continue to flout such provisions by placing few restrictions on media reporting of criminal cases involving juveniles. Amidst political clamours for ever more punitive measures to deal with youth crime other jurisdictions now seem bent upon following the NT's approach. A notable and largely unnoticed exception to this trend is to be found in New South Wales where in a recent inquiry, conducted by the NSW Legislative Council's Law and Justice Standing Committee, it has been recommended that not only should the privacy protections afforded young people be maintained but uniform laws should be introduced on this subject. This recommendation has since been accepted by the NSW Government. In this Comment, which updates earlier remarks on this issue published in 2007 , an account is given of the inquiry's findings and recommendations, together with a call for research to establish the impact of naming and shaming young people in jurisdictions like the NT.
\end{abstract}

\section{Disciplines}

Law

Publication Details

D. Chappell \& R. Lincoln, 'Shhh ... we can't tell you: an update on the naming prohibition of young offenders' (2009) 20 (3) Current Issues in Criminal Justice 476-484. 


\title{
'Shhh ... We Can't Tell You': An Update on the Naming Prohibition of Young Offenders
}

\begin{abstract}
Prohibitions on the naming of young offenders in criminal proceedings remain a controversial issue both in Australia and abroad. Despite international obligations, like those contained in the UN Convention on the Rights of the Child, to protect the privacy of young people in conflict with the law jurisdictions like the Northern Territory (NT) continue to flout such provisions by placing few restrictions on media reporting of criminal cases involving juveniles. Amidst political clamours for ever more punitive measures to deal with youth crime other jurisdictions now seem bent upon following the NT's approach. A notable and largely unnoticed exception to this trend is to be found in New South Wales where in a recent inquiry, conducted by the NSW Legislative Council's Law and Justice Standing Committee, it has been recommended that not only should the privacy protections afforded young people be maintained but uniform laws should be introduced on this subject. This recommendation has since been accepted by the NSW Government. In this Comment, which updates earlier remarks on this issue published in 2007 , an account is given of the inquiry's findings and recommendations, together with a call for research to establish the impact of naming and shaming young people in jurisdictions like the NT.
\end{abstract}

\section{Right to Publish vs Right to Protection}

Under the headline of 'Shhhh ... we can't tell you' the Northern Territory News on 21 February this year reported on a juvenile sentencing matter where the magistrate 'ordered that the Darwin court be closed to all but those directly involved in the hearing' (Watkins \& Adlam 2009). The article claimed that the magistrate had 'banned' the news organisation and any others 'from publishing the full details of a high-profile criminal case'. The newspaper's deputy-editor was quoted as saying that 'it is important that justice be delivered in public. ... We can see no reason why full details shouldn't be published. We live in a democracy and people have a right to know what is going on in their courts and community. Our readers should have been able to be fully informed of this case' (Watkins \& Adlam 2009). Yet, there had been no such prohibition on publicity surrounding this matter when it was first dealt with, and it was apparently widely reported at the time.

This example demonstrates some of the inherent difficulties of the Youth Justice Act (2006) of the Northern Territory permitting the naming of youthful offenders, except where specific applications might be made to suppress such identifying information. In all other jurisdictions in Australia, young people involved in criminal proceedings are afforded protections under juvenile justice laws so that their identities remain hidden, although again exceptions are permitted. In this case the identity protection provided to this young person by the sentencing magistrate in Darwin, while admirable, came somewhat belatedly as the case had already become 'high-profile' and prior media coverage canvassed extensive details of the offences and the offender. The case highlights the inconsistencies, both within and between jurisdictions in Australia, and indicates why this issue remains contentious at the local, national and international levels. 
We addressed aspects of this issue in a CICJ comment almost two years ago (Chappell \& Lincoln 2007), but there have been some critical and recent developments. In particular, a New South Wales Legislative Council (NSWLC) inquiry has made important recommendations for reform, most of which have been accepted by the NSW Government, and one of which is under referral to the Standing Committee of Attorneys-General (SCAG) for national attention. The NSWLC inquiry report (NSWLC 2008) is well-written and documented, reflecting the quality of the many and varied submissions made to it, yet it has received little to no public attention. This is surprising given the media's interest in this issue, the accessibility of the report, and the government's endorsement of most of its recommendations. In this comment we describe the nature of those recommendations, examine some of the key pieces of evidence presented in submissions to the committee, and foreshadow possible law reform and related policy developments, with a particular focus on the dire need for empirical evidence on this practice.

\section{NSWLC Inquiry and Government Response}

As we reported in our earlier comment a landmark case in this area is the 2006 NSWCCA decision in John Fairfax Publications Pty Ltd re MSK, MAK, MMK and MRK. In this case John Fairfax Pty Ltd (publishers of the Sydney Morning Herald and The Age) made an unsuccessful appeal court application in NSW to have a name suppression order removed on two juveniles and their co-offending adult siblings. While the appeal was resolved on jurisdictional grounds (i.e. applications of this type to lift suppression of names should occur at the time of sentencing), the case, because of its high-profile nature, led to a reference by the NSW Attorney-General to the multi-party Law and Justice Standing Committee of the NSW Legislative Council to inquire into the 'prohibition on the publication or broadcasting of the names of young people who are involved in criminal proceedings' (NSWLC 2008:iv). The reference noted that 'such public focus highlighted the need to reconsider the prohibition on naming young offenders who have been charged with serious crimes' (NSW Government 2008:1).

The following terms of reference were set for the NSWLC inquiry by the Attorney General and Minister for Justice regarding the current prohibitions embedded in s11 of the NSW Children (Criminal Proceedings) Act 1987 ( NSWCCPA):

1. The extent to which the policy objectives of the prohibition remain valid, including to:

(a) reduce the community stigma associated with a child's involvement in a crime, thereby allowing the child to be reintegrated into a community with a view to full rehabilitation;

(b) protect victims from the stigma associated with crimes; and

(c) reduce the stigma for siblings of the offender and victim, allowing them to participate in community life.

2. The extent to which section 11 of the Act is achieving these objectives.

3. Whether the prohibition and broadcasting of names under section 11 of the Act should cover:

(a) Children who have been arrested, but who have not yet been charged;

(b) Children, other than the accused, who are reasonably likely to be involved in proceedings; and/or

(c) Any other circumstance. 
In late 2007, after receiving a total of 27 written submissions, the NSWLC committee held three days of public hearings with 26 witnesses appearing before it. Submissions or evidence were taken from victims' support groups such as VOCAL; youth legal aid bodies like the Shopfront Youth Legal Centre; state government bodies such as police, the DPP and juvenile justice agencies together with legal aid and public defender offices; federal agencies like the Human Rights and Equal Opportunities Commission and the Australian Law Reform Commission; and media bodies like the Australian Press Council.

The NSWLC committee reported its findings in April 2008 and the government responded in August, accepting all but two of the eight recommendations made by the committee. This comment focuses on a number of these: most specifically those relating to the need for uniform laws, the scope of protection afforded to young people, certain procedural matters regarding the waiver of protections, and the need for research.

\section{Need for Uniform Laws}

The committee's principal recommendation was 'that the NSW Attorney General seek cooperation from the Attorneys General in other states and territories in implementing a consistent prohibition relating to the publication of names of children involved in criminal proceedings regardless of in which state those criminal proceedings occur' (NSWLC 2008:61). In doing so the committee supported 'the view expressed by many Inquiry participants including the NSW Public Defenders Office, Deputy Chief Magistrate Helen Syme and Mr Nicholas Cowdery AM QC, the NSW Director of Public Prosecutions, that names are not essential details when reporting on criminal proceedings involving children and that the public can be adequately informed about a particular case without the inclusion of the names of juveniles involved' (NSWLC 2008:59). The committee noted the distinction between being 'of' versus 'in' the public interest, and while endorsing the need for open justice, observed that the exceptions available under s11 to lift a suppression order meant that a considered appraisal could be made about whether to name or not at the time of sentencing.

The committee described the cross-jurisdictional difficulties where the 'policy objective of section 11 in protecting juveniles from the stigma of association with a crime has effect only in NSW. If a juvenile were to move to another state where the publication of their name had been allowed, they may be subjected to that very stigma', and vice versa (NSWLC 2008:60). Thus they suggested the need for uniform legislation because the media operates across jurisdictional boundaries. This recommendation was accepted by the government because it was thought to be of 'the utmost importance, particularly given technological advances in publishing and broadcast formats such as Internet news sites which allow for immediate nation-wide reporting' (NSW Government 2008:2). The NSW Attorney-General in accepting this recommendation indicated that the matter would be referred to the SCAG for further consideration. It is not known at this juncture what the outcome of this referral is.

In Table 1 below a summary is provided of the various measures currently in force around the country regarding the publication of names and other identifying information about young persons involved in criminal proceedings. It will be seen that considerable diversity exists in the statutory wording used and that the nature and scope of the protection afforded is far from uniform. 
Table 1: Summary Excerpts of Relevant Clauses in Juvenile Justice Legislation in Australian Jurisdictions

\begin{tabular}{|c|c|c|}
\hline & Legislation & Publication of Names Clauses \\
\hline ACT & $\begin{array}{l}\text { Children and } \\
\text { Young People Act } \\
1999\end{array}$ & $\begin{array}{l}\text { Sec. } 61 \mathrm{~A}(3) \text { A person must not publish an account or report } \\
\text { of the proceeding if the account or report - (a) discloses the } \\
\text { identity of the child or young person or a family member; or } \\
\text { (b) allows the identity of the child or young person, or a } \\
\text { family member, to be worked out. }\end{array}$ \\
\hline NSW & $\begin{array}{l}\text { Children (Criminal } \\
\text { Proceedings) Act } \\
1987\end{array}$ & $\begin{array}{l}\text { Sec. 11(1) The name of any of the following persons must not } \\
\text { be published or broadcast in a way that connects the person } \\
\text { with the criminal proceedings concerned: (a) any person who: } \\
\text {... (ii) was a child when the offence to which the proceedings } \\
\text { relate was committed ... }\end{array}$ \\
\hline NT & $\begin{array}{l}\text { Youth Justice Act } \\
2006\end{array}$ & $\begin{array}{l}\text { Sec. } 50(1) \text { The Court may, in an order under section } 49 \text { or by } \\
\text { a separate order, direct that a report of, or information relating } \\
\text { to, proceedings in the Court, or the result of proceedings } \\
\text { against a youth before the Court, must not be published. }\end{array}$ \\
\hline QLD & $\begin{array}{l}\text { Juvenile Justice } \\
\text { Act } 1992\end{array}$ & $\begin{array}{l}\text { Sec. } 301(1) \text { A person must not publish identifying } \\
\text { information about a child ... }\end{array}$ \\
\hline SA & $\begin{array}{l}\text { Young Offenders } \\
\text { Act } 1993\end{array}$ & $\begin{array}{l}\text { Sec. } 13(1) \text { A person must not publish, by radio, television, } \\
\text { newspaper or in any other way, a report of any action or } \\
\text { proceeding taken against a youth by a police officer or family } \\
\text { conference ... }\end{array}$ \\
\hline TAS & $\begin{array}{l}\text { Youth Justice Act } \\
1997\end{array}$ & $\begin{array}{l}\text { Sec. } 31(1) \text { A person must not publish any information in } \\
\text { respect of any proceedings that ... may lead to the } \\
\text { identification of, a youth who is the subject of or a witness in } \\
\text { the proceedings... }\end{array}$ \\
\hline VIC & $\begin{array}{l}\text { Children and } \\
\text { Young Persons Act } \\
1989\end{array}$ & $\begin{array}{l}\text { Sec. } 26(1) \text { A person must not publish or cause to be published } \\
\text { - (a) ... any particulars likely to lead to the identification of - } \\
\text { (i) the particular venue of the Children's Court ... in which the } \\
\text { proceeding was heard; or (ii) a child or other party to the } \\
\text { proceeding; or (iii) a witness in the proceeding... }\end{array}$ \\
\hline WA & $\begin{array}{l}\text { Children's Court } \\
\text { of WA Act } 1988\end{array}$ & $\begin{array}{l}\text { Sec. } 35(1) \text {... a person shall not publish or cause to be } \\
\text { published in any newspaper or other publication or broadcast } \\
\text { or cause to be broadcast by radio or television a report of any } \\
\text { proceedings ... containing any particulars or other matter } \\
\text { likely to lead to the identification of a child who is concerned } \\
\text { in those proceedings ... }\end{array}$ \\
\hline
\end{tabular}

Note: Legislation provides discretion in all jurisdictions for the courts to waive these protections (but these exceptions are not included in the Table).

\section{Scope of the Protections}

Another important matter considered by the NSWLC committee under its terms of reference was the extension of protections to the pre-arrest and preliminary investigatory stages of criminal proceedings involving young people. Under the current drafting of s11 of the 
NSWCCPA, identity prohibition is only invoked once "charges are laid or a court attendance notice is issued' (NSW Government 2008:4). Many submissions to the inquiry pointed to the incongruity of this situation, where a young person could be identified in the media, then later be charged, where the impact of s11 protections would be diminished by earlier publicity. The Youth Justice Coalition noted how such circumstances are 'inconsistent with the principles underlying the justice system, including the presumption of innocence' (NSWLC 2008:73). Similarly, the Deputy Senior Public Defender, Andrew Haesler, in endorsing such an extension, described the anomalous situation where 'you could have a young person who is, say, arrested in a blaze of publicity, if there was not a prohibition about pre-charging, or investigated in a blaze of publicity and then suddenly there is silence and they are living in a community where they cannot get out to the media the fact that all the charges have been dropped or he has been acquitted' (NSWLC 2008:74). Other submissions highlighted discrepancies between the provisions of s11 and the Youth Offenders Act 1997 (NSW), especially as naming might relate to young people who undergo restorative conferencing procedures.

The NSW DPP and counsel for the police service also saw merit in this extension, although the police did express reservations about operational difficulties that might arise. The committee were attentive to potential procedural difficulties (both for the police and media) but their final recommendation (Recommendation 4) was framed to ensure that any juvenile who is a suspect or who is 'reasonably likely' (NSWLC 2008:79) to become one should be covered by the current legislation. The committee said that "the arguments ... are essentially the same as those in favour of its application to the period after charging - that is, to reduce the stigma associated with a juvenile's involvement in criminal proceedings and the potential for long term damage' (NSWLC 2008:78).

This particular recommendation is one that was rejected by the NSW Government on the basis that extending the prohibition to the pre-arrest and investigatory phases is not permitted in any other jurisdiction and thus the government view was that a broadening of the reach of the prohibition would impede calls for uniformity across Australian jurisdictions. It also seems that this recommendation failed to be endorsed on the basis that NSW did not wish to lead law reform in this area, but the issue clearly requires more detailed consideration by SCAG.

The case of a 16-year-old in Melboume who held a party at his house in his parents' absence shows how a local story can now achieve instant international reach. The party, advertised on the Internet, attracted 500 guests and following calls to police by neighbours it is alleged that 'up to 30 police were called to the party, along with dog squads, transit police, divisional vans and a critical incident response team' (Burgess 2008). The teenager and his parents were besieged by local media with commercial television and newspaper reporters contacting them and their neighbours. The story 'made world headlines' including being covered by the BBC and The Guardian (Burgess 2008). The young person's name, photograph, home address along with quotes were included in those news items. Victoria Police, at one stage, debated whether the young person should pay the costs of the police intervention which ran to tens of thousands of dollars. In late 2008 his mother was charged with obstructing police and placed on a good behaviour bond as a result of the media intrusions and police attention they received following the party (Pilcher 2008). Clearly, the young man achieved celebrity status but the media attention also caused embarrassment and consequences for him and his family. 


\section{Conditions of Waiver of Protection}

A related and important proposal (Recommendation 6) made by the NSWLC committee is concerned with juveniles between the ages of 16 and 18 who under the legislation may consent to the waiving of the prohibition. At present this can be done unilaterally but the government concurred with the NSWLC committee's recommendation to provide additional protections, in the form of seeking advice so that any waiver or consent must be done through legal counsel, or with an appropriate adult present. Again this relates to the recommendation above which seeks to extend the protections to the investigatory phase of criminal proceedings.

Without protections prior to arrest young people can be named and identified in the local, national and even international media before any charges are brought, or indeed could consent to the publication of their identities not fully cognisant of the ramifications, as in the case of the infamous 'party pest' in Melbourne described above. It may be that the young person is not sufficiently mature, or may well be trying to gain public notoriety without being fully appraised of the consequences of waiving the prohibition. Despite some submissions which strongly advocated the differentiation of younger versus older youth, the NSWLC inquiry preferred to treat all juveniles the same rather than distinguishing between age groups, recognising the difficulties in adjudicating whether one 15 -year-old is mature enough to make a decision compared to another who might be 16 years.

\section{Procedural Matters}

Two of the NSWLC committee recommendations ( $2 \& 3$ ) deal with the operational oversight of the legislation and how police handle complaints that breach s11, along with the need for uniform methods for reporting and dealing with such breaches. Under these proposals is a strategy to educate sections of the police service about what constitutes a breach under s11 of the Act as well as communication to relevant agencies (e.g. legal aid) on the basis that 'it is vital for the effective operation of the prohibition on the naming of juveniles that the reporting processes are well known and readily available to those most likely to be affected' (NSW Government 2008:3).

Of the remaining recommendations, two (5 and 8 ) relate to procedural aspects for law enforcement agencies, judicial officers and the courts to ensure that their work is not affected by the protections for juveniles. The NSW Government agreed with the view of the NSWLC committee that the current legislation is not intended to impinge on the legitimate work of the police or courts (in detailing the names of juveniles in hearings lists, for example), and that it is the public/media identification which is the focus of s11. Thus these two recommendations are aimed at ensuring that there should be no misconstruing of the legislation in a restrictive fashion.

Recommendation 7 of the NSWLC committee canvassed extending the prohibition on identifying features for juveniles to civil proceedings in addition to criminal proceedings. This proposal was summarily dismissed in the NSW Government response, as not forming any part of the original terms of reference to the NSWLC inquiry.

\section{The Need for Research: Perceptions versus Evidence}

There is little doubt that the NSWLC inquiry, and its associated report, represents the most comprehensive and authoritative review conducted so far in this country of the important 
issues associated with the special privacy protections afforded young people when confronted by criminal proceedings. Even so, much of the discussion and debate about the merits of these protections by proponents and opponents alike rest upon perceptions and impressions, rather than upon evidence garnered from objective research. For example, a number of submissions and evidentiary claims were made about the beneficial aspects of media shaming, or the need for victims of crime (whether adult or child) to be afforded greater recognition and redress via the naming of the youthful offenders involved. The problem is that there are no empirical data to underscore such claims in particular, or to ascertain at large the consequences of naming. Evidence is lacking about whether the public naming of juveniles has specific or general impacts, which groups are most likely to be affected, what is the extent and scope of any media coverage, and under what circumstances are the legislative exceptions invoked. To this end, we have made application for research funding to gather quantitative and qualitative data across several jurisdictions about media coverage, via interviews with key stakeholders, and to explore specific cases that have attracted significant media attention.

There are, of course, existing bodies of empirical research which suggest quite strongly that the naming and shaming of young people involved in criminal proceedings have detrimental impacts, with little evidence of the alleged benefits raised by its proponents. First there is the corpus of work on the effects of labelling dating back to Becker in the 1960 s where stigmatisation is apt to lead to higher levels of deviance. More recently, the theory of reintegrative shaming (drawn in part from the labelling perspective) suggests that shaming which is reintegrative (respectful and healing) is more likely to result in lower rates of recidivism than degrading or stigmatising shame (Braithwaite 1989). While some empirical studies have been conducted on shaming and its relationship to compliance or recidivism (see Murphy \& Harris 2007) most tend to focus on white-collar offenders. In the evaluative research on restorative justice and youth conferencing the concepts of shame and stigmatising have been addressed but they are tangential to the factors involved in the media-naming of juveniles (see Sherman \& Strang 2007). Finally, there is a significant body of research in Australia that focuses on representations of young people (see Bessant \& Hil 1997), and particularly Indigenous youth (see Sercombe 1995), in the mass media. But none of these provide direct evidence of the impacts, negative or otherwise, of the mass media naming of young people involved in criminal proceedings. Thus we are pursuing such a research agenda.

\section{Conclusions}

In our previous comment we concluded that there would likely be a number of detrimental outcomes arising from any disclosure of the identity of young offenders. These include: a misuse of the concept of shaming, the potential for vigilante action, a false sense of community protection, and the possibility of interfering with any rehabilitative efforts. The NSWLC inquiry now lends considerable force and persuasion to the view that outcomes of this nature should be avoided, and that the existing privacy protections should not only be maintained but extended to an earlier stage in criminal proceedings.

Regrettably, and perhaps because of the lack of publicity and discussion associated with the NSW inquiry report and the recommendations it contains, there have already been recent calls in the current election campaign in Queensland where Premier Anna Bligh has indicated greater 'opportunities for judges to name juveniles' (ABC Local 1 March 2009) which was given support by the Opposition Leader, Lawrence Springborg, especially as a 'name and shame' campaign had been part of the 2001 electioneering. Similar calls have 
been made in Western Australia in the last few years where most recently Attorney-General Christian Porter broached possible legislative change 'to identify some violent criminals as young as 16' (West Australian 19 December 2008).

Australian jurisdictions are not alone in seeking to have young people named when they are involved in indictable crimes. Recently in Canada this issue was canvassed after the murder of a 22 -year-old by a then 17-year-old on a city bus. The case garnered wide media attention, and at the recent sentencing hearing the prohibition on naming the offender was lifted because of the 'seriousness of this crime' (Blatchford 2009). The movement to publicly name juvenile offenders is clearly gathering momentum and demonstrates that long-held protections for youthful offenders, and the international conventions that support them, are slowly being eroded, if not abandoned in favour of more politically expedient and popular positions. It is to be hoped that when it comes to consider the desirability of a uniform national approach to the naming of young offenders SCAG will recognise Australia's obligations under international conventions, rather than pander to populist views based on untested and dubious evidence.

\section{Duncan Chappell and Robyn Lincoln}

Duncan Chappell is Professorial Fellow, Centre for Transnational Crime Prevention, University of Wollongong and Adjunct Professor, Faculty of Law, University of Sydney, duncanc@uow.edu.au. Address for correspondence: Professor Duncan Chappell, Faculty of Law, University of Wollongong, Wollongong NSW 2522. Robyn Lincoln is Assistant Professor, Criminology, Bond University, rlincoln@staff.bond.edu.au.

\section{Case}

Judgement in the Application by John Fairfax Publications Pty Ltd re MSK, MAK, MMK and MRK [2006] NSWCCA 386

\section{References}

ABC Local 2009 'Bligh Pledges \$57 million for Green Army' 1 March $<$ www.abc.net.au/news/stories/2009/03/01/2504340.htm?site=local>

Becker H 1963 Outsiders: Studies in the Sociology of Deviance Free Press New York

Bessant J \& Hil R (eds) 1997 Youth, Crime and the Media: Media Representations of and Reactions to Young People in Relation to Law and Order National Clearinghouse for Youth Studies Hobart

Blatchford C 2009 'Ipod Killer Gets Adult Sentence for Murder on Ottawa City Bus' Toronto Globe and Mail 13 February <www.theglobeandmail.com/servlet/ story/LAC.20090213.BLATCH13/>

Braithwaite J 1989 Crime, Shame and Reintegration Cambridge University Press Cambridge

Burgess M 2008 'Party Boy Achieves Global Notoriety' Melbourne Age 15 January $<$ www.theage.com.au/news/national/party-boy-goesglobal/2008/01/15/1200159414201.html> 
Chappell D \& Lincoln R 2007 'Abandoning Identity Protection for Juvenile Offenders' Current Issues in Criminal Justice vol 18 no 3 pp 481-487

Murphy K \& Harris N 2007 'Shaming, Shame and Recidivism: A Test of Reintegrative Shaming Theory in the White-Collar Crime Context' British Journal of Criminology vol 47 pp 900-917

NSW Legislative Council Standing Committee on Law and Justice 2008 Inquiry into the Prohibition on the Publication of Names of Children Involved in Criminal Proceedings Report No 35 NSW Government Publisher Sydney

NSW Government 2008 NSW Government Response to the Legislative Council Standing Committee on Law and Justice Inquiry into the Prohibition on the Publication of Names of Children Involved in Criminal Proceedings NSW Government Publisher Sydney

Pilcher G 2008 'Corey Worthington's Mum on Good Behaviour Bond' Herald-Sun 15 October <www.news.com.au/heraldsun/story/0,24499692-662,00.html>

Sercombe H 1995 'The Face of the Criminal Is Aboriginal: Representations of Aboriginal Young People in the West Australian Newspaper' in Bessant J, Carrington K \& Cook S (eds), Cultures of Crime and Violence: The Australian Experience La Trobe University Press and Victorian Law Foundation Melbourne

Sherman L \& Strang H 2007 Restorative Justice: The Evidence The Smith Institute London

Watkins E \& Adlam N 2009 'Shhh ... We Can't Tell You' Northern Territory News 21 February <www.ntnews.com.au/article/2009/02/21/34625_ntnews.html>

West Australian 2008 'Name and Shame Three Teenagers Who Bashed my Wife, Pleads Fearful Husband' West Australian 19 December <www.thewest.com.au/default.aspx? MenuID $=77 \&$ ContentID=113971> 
